Warren, Christine; Gusman, Jake; Teal, Martin J.; Hunnemann, Mike; Matsuda, Curtis

From Auwaiakeakua to Weoweopilau: Assessing Scour Critical Bridges in Hawaii (It's a Tough Job, But Someone Has To Do It)

Verfügbar unter / Available at:

https://hdl.handle.net/20.500.11970/100226

Vorgeschlagene Zitierweise / Suggested citation:

Warren, Christine; Gusman, Jake; Teal, Martin J.; Hunnemann, Mike; Matsuda, Curtis (2010): From Auwaiakeakua to Weoweopilau: Assessing Scour Critical Bridges in Hawaii (It's a Tough Job, But Someone Has To Do It). In: Burns, Susan E.; Bhatia, Shobha K.; Avila, Catherine M. C.; Hunt, Beatrice E. (Hg.): Proceedings 5th International Conference on Scour and Erosion (ICSE-5), November 7-10, 2010, San Francisco, USA. Reston, Va.: American Society of Civil Engineers. S. 864-873. 


\title{
From Auwaiakeakua to Weoweopilau: Assessing Scour Critical Bridges in Hawaii (It's a Tough Job, But Someone Has To Do It)
}

\author{
Christine Warren ${ }^{1}$, P.E., Jake Gusman ${ }^{2}$, P.E., Martin J. Teal ${ }^{3}$, P.E., P.H., \\ Mike Hunnemann ${ }^{4}$, P.E., Curtis Matsuda ${ }^{5}$, P.E.
}
${ }^{1}$ WEST Consultants, Inc., Senior Hydraulic Engineer, 11440 W. Bernardo Court, Suite 360, San Diego, CA 92127. Email: cwarrenawestconsultants.com
${ }^{2}$ WEST Consultants, Inc., Project Manager, 11440 W. Bernardo Court, Suite 360, San Diego, CA 92127.
${ }^{3}$ WEST Consultants, Inc., Vice President, 11440 W. Bernardo Court, Suite 360, San Diego, CA 92127.
${ }^{4}$ KAI Hawaii, Inc., Vice President, 31 N. Pauahi Street, $2^{\text {nd }}$ Floor, Honolulu, HI 96817.
${ }^{5}$ Hawaii DOT, Hydraulic Design Engineer, Highways Division, 601 Kamokila Blvd, Room 636, Kapolei, HI 96707.

\begin{abstract}
In the State of Hawaii, nearly 60 bridges have been identified as potentially scour critical based on observed or anticipated conditions at the bridges. The Hawaii Department of Transportation (DOT) is preparing a Plan of Action (POA) for each bridge that will outline procedures for Hawaii DOT personnel to follow during high flow events to help ensure public safety. Each POA will include a scour vulnerability assessment, recommended actions including hydraulic/structural countermeasures, increased inspections, and/or flood monitoring, and a bridge closure plan. Waterways involved range from large, sand-bed rivers along the coastline of Oahu to the steep, rocky Hamakua Coast on the Big Island. A number of bridges on the historic Hana Highway on Maui are also included. Drainage areas range from less than $0.5 \mathrm{~km}^{2}$ to nearly $650 \mathrm{~km}^{2}$. Flows were developed for each bridge based on available data along with a detailed hydraulic analysis. Scour vulnerability was determined based on contraction and pier scour depths using HEC-18 guidelines.
\end{abstract}

\section{INTRODUCTION}

The Federal Highway Administration (FHWA) has collected information on nearly 600,000 of the nation's bridges and created the National Bridge Inventory (NBI) database. This database includes the number, location, and general condition of bridges in each state. Item 113 in the database is used to indicate the status of each bridge regarding scour vulnerability. A bridge is identified as scour critical if the value for Item 113 is between 0 and 3, with a value of 3 indicating that the bridge foundations were determined to be unstable based on a calculated or assessed scour depth being at or below the footing base or pile tips, and a value of 0 indicating the bridge has failed and is closed to traffic (FHWA, 1995). In the State of Hawaii, 57 bridges have been identified as scour critical on the NBI database. These bridges are spread throughout the five major islands and include those on Oahu (22), Kauai (10), Hawaii (13), Maui (10), and Molokai (2). A summary is provided below of the bridges located on each of the islands. 


\section{Island of Oahu}

The Island of Oahu is the most populated of the Hawaiian Islands and also has the most developed highway system. Twenty-two bridges were determined to be scour critical and their locations are shown in Figure 1. The bridges encompass the entire island and they cover a wide variety of hydraulic and hydrologic characteristics. Drainage areas range from $0.4 \mathrm{~km}^{2}$ for Kapalaau Stream to $100 \mathrm{~km}^{2}$ for Kaukonahua Stream, both located on the northwest side

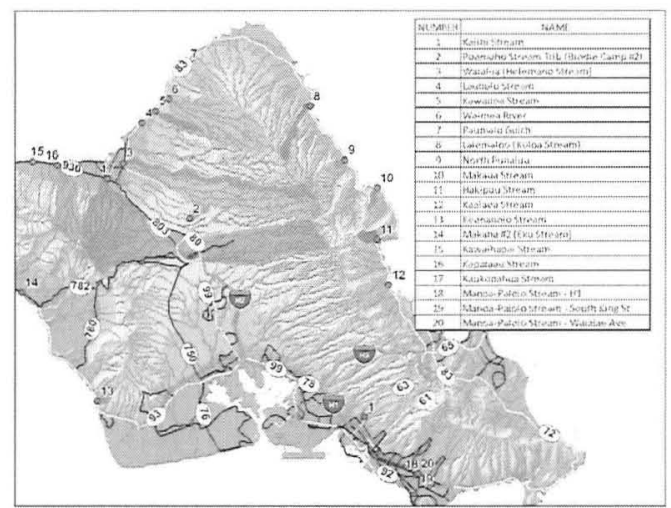

Figure 1. Oahu Scour Critical Bridges of the island on State Highway 930 near Waialua. There are bridges that cross steep, gravel bed streams on the east coast of the island near Kaneohe Bay and those that cross relatively flat, sand bed streams near Waimea Bay along the scenic and popular North Shore. The Manoa-Palolo and Kalihi Stream bridges are located in the urbanized city of Honolulu, while a large number of bridges are in more rural areas. The majority of the bridges are located on the coastal highway loop that consists of the Kamehameha and Farrington highways. Only six bridges are located more than 500 feet from the Pacific Ocean.

\section{Island of Kauai}

The Island of Kauai is the oldest of the Hawaiian Island and is nicknamed the Garden Isle because of its lush vegetation. Ten bridges were identified as scour critical and their locations are shown in Figure 2. All the bridges are along the Kaumuali and Kuhio Highways that circle the island. The Waimea River bridge has a drainage area of $222 \mathrm{~km}^{2}$ and is home to the spectacular Waimea Canyon, which is over a mile wide and is the deepest non-submarine

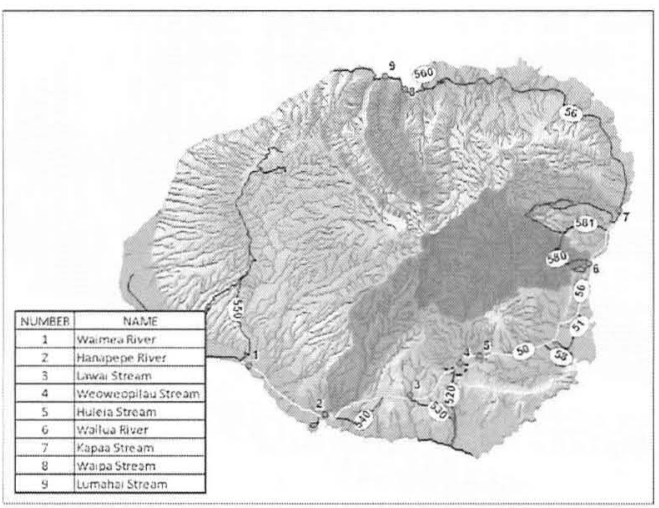

Figure 2. Kauai Scour Critical Bridges canyon in the Pacific with depths up to 3,000 feet. At the center of the island is Mount Waialeale which is considered the "wettest place on earth". The watersheds for all 10 bridges extend from the slopes of Mount Waialeale to the Pacific Ocean. 


\section{Island of Hawaii}

The Island of Hawaii is the largest of the Hawaiian Islands and is commonly called the Big Island with its area being twice the size as all the other islands combined. Regardless of its size, only thirteen bridges were identified as scour critical and they are all located on the northern side of the island as shown in Figure 3. Twelve of the bridges are located along the Hawaii Belt Road (H-19) that follows the coastline around the northern half of the island and eleven of

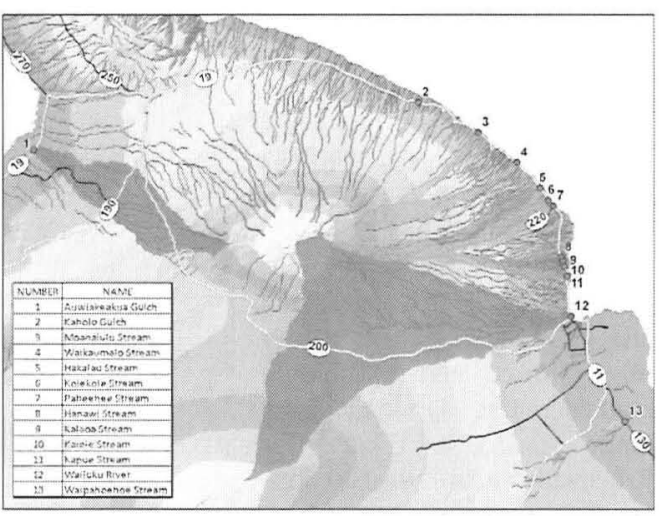

Figure 3. Hawaii Scour Critical Bridges

these are within a 20 mile stretch on the northeastern side referred to as Hamakua Coast. This stretch of coast is comprised of steep, rocky streams and high cliffs that drop to the ocean. Drainage areas range in size with the largest at $641 \mathrm{~km}^{2}$ for Wailuku River. The headwaters for Wailuku River begin at the peaks of Mauna Loa and Mauna Kea volcanoes and the river enters the Pacific Ocean in the City of Hilo. Due to its size and proximity to the ocean, the Wailuku Bridge will not only be subject to riverine scour, but also scour from a tsunami-generated tidal bore.

\section{Island of Maui}

The Island of Maui is often called the Valley Isle for its beauty and is the second most visited of the Hawaiian Islands, only second to Oahu. Ten bridges were identified as scour critical and their locations are shown in Figure 4. Four of the bridges are located along Highway 30 which circles the northwestern part of the island. Four bridges are located on the historic Hana Highway on the northern coastline and have construction dating as far back as 1912. The

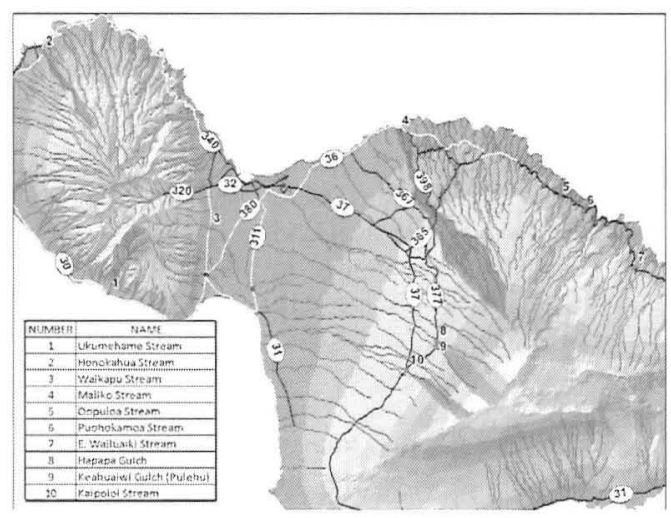

Figure 4. Maui Scour Critical Bridges remaining three bridges are further inland and lie on the western slope of Haleakala volcano. Drainage areas range from as small as $1.4 \mathrm{~km}^{2}$ for Oopuola Stream to 35.2 $\mathrm{km}^{2}$ for Maliko Stream. 


\section{Island of Molokai}

Although the Island of Molokai has the smallest population of the five major Hawaiian Islands, it has the largest population of native Hawaiians and is often referred to as the Friendly Isle or the Most Hawaiian Island. Only two bridges were identified as scour critical and their locations are shown in Figure 5. Both bridges are located along Highway 450 on the southern coastline of the eastern half of the island. Both bridges drain the southern side

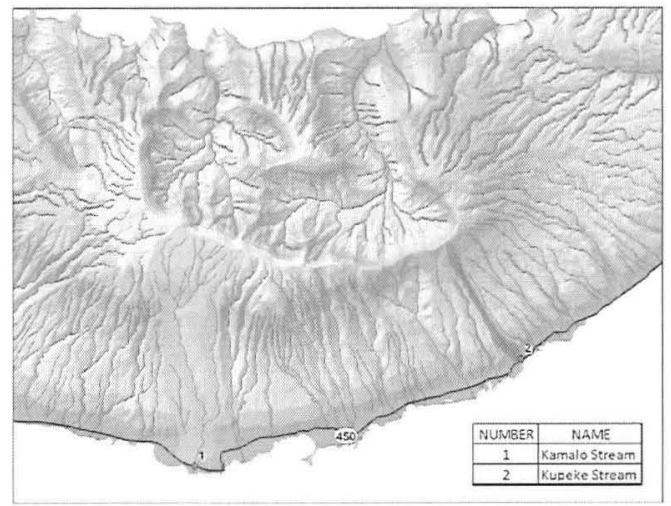

Figure 5. Molokai Scour Critical Bridges

of Kamakou Volcano which can receive up to 300 inches of rain annually. The watersheds are heavily forested and have drainage areas of $1.1 \mathrm{~km}^{2}$ for Kupeke Stream and $11.9 \mathrm{~km}^{2}$ for Kamalo Stream.

\section{HYDROLOGY}

The Islands of Hawaii are subject to prevailing winds that blow from the northeast to the southwest, which splits the islands into two very distinct hydrologic regions. The northern and eastern sides of each island are considered the windward sides and are subject to higher amounts of precipitation and tend to have a lush, green landscape. The southern and western sides of each island are considered the leeward sides and are protected from the wind and precipitation by high elevations on the interior of each island. The leeward sides generally have a more arid or semi-arid landscape. The scour critical bridges are comprised of watersheds that are located on both the windward and leeward sides of the islands and will in turn have a variety of hydrologic properties.

Peak flows for each scour critical bridge were determined from a number of available sources including published flows derived from FEMA Flood Insurance Studies (FIS), USGS streamgage data, or published regional regression equations. FIS reports were obtained for communities that included any of the scour critical bridge reaches as flooding sources. In some instances, peak flows from the FIS reports were discarded due to outdated hydrologic techniques or the location on the stream where the flow was defined. In these instances, further analysis was required to estimate peak flows using flood frequency analysis or regional regression equations.

\section{Flood Frequency Analysis}

Annual peak discharges were retrieved from the USGS's national streamflow database (USGS, 2009) for streamgages located on study reaches. Peak flows were estimated for the 100-year and 500-year events using the U.S. Army Corps of 
Engineers Statistical Software Package HEC-SSP (USACE, 2009). The software package follows the guidelines in Bulletin 17B (Interagency Advisory Committee on Water Data, 1982), which recommend the use of the Log Pearson Type III distribution as a base method for flood frequency studies.

If a bridge was located on a stream with a gage, but is downstream or upstream of the streamgage, a drainage area comparison was performed to determine whether the gage could be used to calculate peak flows at the bridge. If the drainage area at the bridge was within 0.5 to 1.5 times the drainage area at the streamgage, peak flows at the bridge could be calculated based on the peak flows at the gage using the area weighing procedure below (USGS, 2007).

$$
Q_{u}=\left[\frac{A_{u}}{A_{g}}\right]^{b} Q_{g}
$$

where $Q_{u}$ is the weighted peak flow estimate for the ungaged bridge site, $A_{u}$ is the drainage area for the ungaged bridge site, $A_{g}$ is the drainage area for the streamgage, $b$ is the drainage area exponent from regional regression equations (or 1 if regression equations are not available), and $Q_{g}$ is the peak flow estimate for the streamgage. If the bridge drainage area is less than 0.5 or greater than 1.5 times the streamgage drainage area, regression equations were obtained or developed to determine peak flow estimates at the bridge.

\section{Regional Regression Equations}

For streams with no available FIS report or USGS streamgage data, regional regression equations were used to estimate peak flows. The USGS has recently published regional regression equations for the Islands of Kauai, Oahu, Molokai, Maui, and Hawaii (USGS, 2010) for recurrence intervals ranging from 2 to 500 years. For the regression analysis, the islands were divided into hydrologic regions with peak flow equations developed for each region. An example of the regression equations for the 100-year peak flow for the two Oahu regions is shown below.

$$
\begin{array}{ll}
\text { (Region 3-Oahu Leeward) } & Q_{100}=24.9 D A^{0.65} P^{0.33} \\
(\text { Region } 4-\text { Oahu Windward })) & Q_{100}=516.7 D A^{0.726}
\end{array}
$$

where $Q_{100}$ is the calculated 100 -year peak flow $\left(\mathrm{m}^{3} / \mathrm{s}\right), D A$ is the drainage area at the bridge $\left(\mathrm{km}^{2}\right)$, and $P$ is the median annual precipitation $(\mathrm{mm})$. Values of $P$ were obtained from the Hawaii Rainfall Atlas (HDLNR, 1986). The USGS regional regression equations were used to calculate the 100 -year and 500-year peak flows for the scour critical bridges using the appropriate equations. 


\section{HYDRAULIC MODELING}

A hydraulic model was developed for the majority of the bridges on the scour critical list using the HEC-RAS (River Analysis System) program, version 4.0 (USACE, 2008). A small number of bridges did not require a hydraulic model because the bridge foundations were on solid bedrock with no exposed footings or signs of scour or there was a limited amount of flow that reached the bridge. The HEC-RAS models were developed to obtain hydraulic characteristics at each bridge to use in the scour calculations and countermeasure design, if applicable.

An area of interest (AOI) was delineated for each bridge and included the bridge and extended upstream and downstream several hundred feet. The AOI's provided the limits for obtaining aerial imagery and topographic data for each bridge. Aerial imagery was downloaded from a range of sources including the National Oceanic and Atmospheric Administration (NOAA), Hawaii Coastal Geology Group (http://www.soest.hawaii.edu/coasts/), and the U.S. Department of Agriculture (USDA) Geospatial Data Gateway (http://datagateway.nrcs.usda.gov/). Topographic data was obtained in the format of an InterMap v1.5 digital terrain model (DTM) for each bridge and contours were created from the DTM's. Although the InterMap data proved to be good for many of the bridges, some bridges with dense vegetation rendered the InterMap data unusable and surveyed cross sectional data was required.

For each bridge, the following procedure was used to create the hydraulic model. The ArcGIS program, version 9.1 (ESRI, 2005), with the HEC-GeoRAS extension, was used to extract cross section profiles in the vicinity of the bridge from the DTM. Bridge data was extracted from as-built plans and field measurements and added to the HEC-RAS model. Manning's $n$ values were estimated based on aerial imagery and field observations and contraction and expansion coefficients were increased to 0.3 and 0.5 , respectively, in the vicinity of the bridge. A subcritical flow regime was assumed for the majority of the scour critical bridges; however, there were several steep streams in the study that may require a mixed flow regime. Because the purpose of the study is scour vulnerability, a mixed flow regime will provide the most conservative results and was used where suitable.

\section{SCOUR VULNERABILITY}

The scour vulnerability of each bridge was determined by calculating the scour depth based on the developed HEC-RAS model results and comparing the scour depth to elevations of the existing bridge foundation. The scour depth at each bridge was calculated based on the 100-year flow. However, if the 100-year flow overtopped the bridge, the incipient overtopping flow was determined and used to calculate the scour depth. If the 100-year flow does not overtop the bridge, the 500-year flow was analyzed and if it did not overtop, itwas used to calculate the scour depth.

\section{Scour Calculations}

The total scour depth at each bridge was estimated based on the sum of contraction scour and pier scour (where applicable). Contraction scour occurs when a bridge structure and its embankments cause a constriction to the natural flow area and as a result, velocities increase through the bridge opening. Piers cause scour due to 
the vortex created around the front and sides of the pier. The resulting scour depth is a function of hydraulic characteristics, pier geometry, and bed material size.

Two types of contraction scour can occur in a channel, live-bed or clear-water. Live-bed contraction scour occurs when bed material is transported from the upstream reach into the bridge and clear-water contraction scour occurs when there is no bed material transport. For each bridge, the critical velocity in the approach section was calculated using Laursen's equation (FHWA, 2001) to determine whether live-bed or clear-water scour would occur at the bridge. If the velocity in the approach section exceeded the calculated critical velocity, this indicates the transport of bed material and Laursen's live-bed scour equation (FHWA, 2001) was used to compute contraction scour. If the velocity in the approach section was less than the calculated critical velocity, this indicates no transport of bed material and Laursen's clear-water scour equation (FHWA, 2001) was used to compute contraction scour.

If the bridge structure includes piers, the pier scour depth was calculated using the Colorado State University (CSU) equation (FHWA, 2001). The calculated pier scour depth was then added to the calculated contraction scour depth to obtain the total scour depth at each bridge.

Several of the scour critical bridges have foundations that are constructed on bedrock. Historically, limited guidance has been available to determine scour vulnerability for bridges founded on rock; however, a study recently conducted by the National Cooperative Highway Research Program should provide a methodology for estimating scour vulnerability for these bridges. When this publication is released, it will be used to estimate the scour at the bridges with foundations on bedrock.

\section{Foundations}

Two types of foundations were found at the scour critical bridges, spread footings and pile supported footings. A spread footing is a wide, shallow footing typically made of reinforced concrete. Pile supported footings consist of piles driven through the soil to bedrock or a depth where the soil friction prevents any movement of the pile. Pile footings are common when soil conditions are unable to support bridge loads or in soils that are hard to excavate. For scour vulnerability, spread footings are a higher concern due to the shallow nature of their design.

As-built plans were provided for many of the bridges and the majority included information on the type and depth of the bridge foundation. However, some of the older bridges do not have as-built plans available or the plans did not include details on the foundation. Without this information, a comparison could not be made between the calculated scour depth and foundation elevations. In these scenarios, if the calculated scour depth was of concern, further investigation was necessary to determine the extents of the foundation. Critical elevations of a foundation from a scour vulnerability standpoint are (1) bottom of spread footing, (2) bottom of pile supported footing, and (3) bottom of a pile bent. These are common trigger elevations for streambed monitoring at a bridge (described below).

\section{RECOMMENDED ACTIONS}

Once the scour assessment was completed, the next component of a Plan of Action (POA) was to provide recommended actions for a bridge specific to that 
bridge's scour vulnerability. Recommended actions include one or more of the following: (1) increased inspections, (2) hydraulic and/or structural countermeasures, and (3) flood monitoring. The POA for each bridge outlines the recommended actions to be taken to prevent and/or monitor further scour at the bridge.

\section{Increased Inspections}

Every bridge on the scour critical list for the State of Hawaii currently undergoes an inspection every 24 months. The purpose of a bridge inspection is not only to rate the condition of the bridge superstructure, but also to rate the condition of the abutments, piers, foundations, and note any observed scour or debris build-up. Observing these items on a regular basis can provide insight to whether scour is increasing at a bridge. If a bridge was determined to be scour critical from this study, one recommended action could be to increase the frequency of inspections to a shorter time interval, such as every 12 months. In addition, a single storm event has the potential to produce a large amount of scour; therefore it is imperative to perform inspections after large storms for scour critical bridges.

\section{Hydraulic and/or Structural Countermeasures}

Hydraulic and/or structural countermeasures can be specified as a recommended action in the POA for a bridge. These countermeasures are designed specifically to prevent further scour from occurring while also being cost effective. For bridge abutment protection, countermeasures could include bank and/or bed hardening designs such as riprap, grouted surfaces, gabions, etc., or redirection of flow designs including spur dikes, barbs, bendway weirs, etc. Inline weirs are another countermeasure option that can provide grade control at a bridge. Countermeasures for pier scour mainly consist of hardening the bed around the pier with riprap, gabions, articulated concrete blocks, etc.

Design of the scour countermeasures is based on the results from the HECRAS model for the 100-year flow. Structural retrofitting of a bridge is a structural countermeasure option for the bridge owner; however, it was not a part of this study.

\section{Flood Monitoring}

Each POA specifies when flood monitoring should be initiated based on one or more of the following triggers: (1) water surface elevation reaches a predetermined level on the bridge, (2) discharge or stage at a gaging station reaches a predetermined flow rate or stage, (3) water surface elevation surpasses bankfull and is rising rapidly, (4) an official flood warning for the stream, and (5) predicted rainfall depth to exceed a predetermined amount. Each bridge will have a different set of triggers depending on the presence of a gage station, accessibility to the bridge, etc.

Once flood monitoring is initiated, the POA outlines what type of monitoring should follow, water surface elevation monitoring and/or streambed elevation monitoring. Streambed monitoring is more useful for bridges with high scour vulnerability because it provides a clearer picture of the scour that may be occurring at the abutments and/or piers, whereas water surface monitoring can only provide an estimate of the scour occurring at that corresponding water surface elevation. 
However, streambed monitoring is not always possible because of lack of accessibility, velocities in the channel during a flood event, cost, etc.

\section{Bridge Closure}

During flood monitoring, bridge closure will be initiated based on a list of criteria in the POA, which is specific to each bridge based on the results of the scour vulnerability assessment. The POA will specify bridge closure if one or more of the following criteria are met (1) water surface elevation reaches a critical elevation, (2) streambed elevation reaches a critical scour elevation (i.e., at or below the bottom of a spread footing), (3) debris buildup causes a significant obstruction of the bridge opening, and (4) any movement of the substructure.

In the case of a bridge closure, each POA includes a contact list that provides a list of personnel that should be notified. Each POA also includes a detour route which may be necessary during a bridge closure. In some remote areas of the islands, a detour route is not feasible and a temporary bridge design may be required instead. This decision is ultimately the choice of the Hawaii DOT.

Once a flood event has subsided and the water surface recedes to an accessible elevation, an inspection should be performed to determine whether the bridge is suitable for reopening. The criteria for reopening can include one or more of the following: (1) assess the post-flood streambed elevations, (2) confirm that no damage has occurred to the substructure, (3) remove any excess debris from the channel that may have accumulated during the flood, and (4) verify the condition of any existing scour countermeasure. The bridge should not be reopened until the required criteria listed on the POA are met.

\section{EXAMPLE PLAN OF ACTION}

Paumalu Gulch is located on the northeastern tip of Oahu (Figure 1) and the drainage area at the bridge is $7.6 \mathrm{~km}^{2}$. Grouted rock has been placed along the abutments and piers as well as loose rock $\left(\sim \mathrm{D}_{50}=15 \mathrm{~cm}\right)$ at the piers as a scour countermeasure; however, the grouted rock is being undermined. The bridge was identified as scour critical and a Plan of Action (POA) was completed and the results are summarized below.

A flood frequency analysis was performed on USGS gage \#16318000, which is located approximately 640 meters upstream of the bridge on Paumalu Gulch. The drainage area ratio between the bridge and gage is equal to 1.1 ; therefore, the 100 year peak flow of $42.2 \mathrm{~m}^{3} / \mathrm{s}$ was calculated based on the area weighting procedure of the estimated flows at the gage.

An HEC-RAS model was created for the bridge based on the DTM, bridge asbuilt plans, and field measurements/observations. Because the 100-year flow did not overtop the bridge, the 500-year flow was modeled and determined to also not overtop and was therefore used for scour calculations. The bed material was determined to be sand with silt and gravel and has a $\mathrm{D}_{50}$ of $0.6 \mathrm{~mm}$. Based on this and results from the HEC-RAS model, contraction and pier scour were calculated to be 0.0 and $2.0 \mathrm{~m}$, respectively, for the 500-year flow. Bridge as-built plans showed the foundation of the Paumalu Gulch Bridge to be wooden piles capped with concrete 
socket piles. Pile tip elevations are unknown and further investigation is required to determine these.

Based on the scour calculations, the POA for Paumalu Gulch Bridge listed recommended actions for the bridge. Placement of riprap with a minimum $\mathrm{D}_{50}$ of 0.5 $\mathrm{m}$ (based on the 100-year flow) at the base of the piers was recommended. Inspection frequencies should be increased to every 12 months, specifically to observe the stability of the grouted riprap and riprap placed at piers. During periods of intense rainfall or flooding, the bridge should be inspected periodically. A 100-year water surface elevation mark ( 4.8 meters below the top of rail on upstream side) should be installed and will act as the trigger elevation to initiate constant flood monitoring. Criteria for closure of Paumalu Gulch Bridge were determined to be when one or more of the following occurs: (1) pressure flow and/or overtopping of the bridge or approach roadways, (2) significant debris buildup in the channel, and (3) any movement of the bridge structure. If bridge closure occurs, the steps to be taken prior to reopening of the bridge are to compare the post-flood streambed elevation to baseline bed elevation, removal of debris accumulated during the high flow, and verify the condition of scour countermeasures.

The preparation of a Plan of Action for each of the 57 scour critical bridges in the State of Hawaii is currently underway and will ultimately outline procedures for Hawaii DOT personnel to follow during high flow events to help ensure public safety.

\section{REFERENCES}

ESRI (2005). Arc GIS Software. Version 9.1, 2005.

FHWA (1995). "Recording and Coding Guide for the Structure Inventory and Appraisal of the Nation's Bridges". U.S. Department of Transportation, Federal Highway Administration, FHWA-PD-96-001, Reston, VA.

FHWA (2001). "Hydraulic Engineering Circular No. 18, Evaluating Scour at Bridges,

Fourth Edition". U.S. Department of Transportation, Federal Highway Administration, FHWA-NHI-01-001, Arlington, VA.

HDLNR (1986). "Rainfall Atlas of Hawaii". Hawaii Department of Land and Natural Resources, Division of Water and Land Development, Honolulu, HI.

Interagency Advisory Committee on Water Data (1982). "Guidelines for Determining Flood Flow Frequency: Bulletin 17B". U.S. Geological Survey, Office of Water Data Coordination, Reston, VA.

USACE (2008). HEC-RAS, River Analysis System. Version 4.0, Hydrologic Engineering Center, Davis, CA.

USACE (2009). HEC-SSP Statistical Software Package. Version 1.1, CPD-86. Davis, CA.

USGS (2007). "The National Streamflow Statistics Program: A Computer Program for Estimating Streamflow Statistics for Ungaged Sites". U.S. Geological Survey, Reston, VA.

USGS (2010). "Flood-Frequency Estimates for Streams on Kauai, Oahu, Molokai, Maui, and Hawaii, State of Hawaii". Scientific Investigations Report 20105035, U.S. Geological Survey, Reston, VA.

USGS (2009). Surface-Water Data for Hawaii, National Water Information System: Web Interface. waterdata.usgs.gov/ne/nwis/sw. 